\title{
Travelling to the described present: mago-space in the Strugatskys' Monday starts on Saturday
}

\section{Путешествие в описываемое настоящее: магопространство в повести Понедельник начинается в субботу

\author{
А. и Б. Стругацких
}

\begin{abstract}
Fantasy and science fiction genres extensively use imaginary settings and locations different from realistic ones but striving to look real. Arkady and Boris Strugatsky, pioneers of the science fiction genre in Russia, actively exploited the potential of both genres in their early tale, Monday starts on Saturday (1964), which combines features of the two space types. The present paper analyses the principles of creating 'mago-space' in the book. To do so, we look at the spatial organization of the events involved in the plot and the personages' ideas regarding space. The research will enable us to clarify the role of space in conveying the authors' message, which in this tale is quite explicit. We argue that the space changes significantly within the book, accompanying genre transformations and the development of the protagonist. Since the tale uses 'mental sublocations' as the main units of spatial organization, each part is determined by a certain type of cultural heritage. In the first part, it is the mental space of folklore and classical literature, in the second - that of mythology and science fiction, and in the final - philosophy and science. Mental spaces that coexist and follow various laws form a narrative which turns out to be a journey to the described present in the variety of its forms.
\end{abstract}

Keywords: the Strugatskys, Monday starts on Saturday, fantasy, science fiction, spatial organization of a literary work

Natalia Tuliakova, Higher School of Economics National Research University, Saint Petersburg Russia,n_tuljakova@mail.ru, ORCID ID: https://orcid.org/0000-0002-0685-4993

Natalia Nikitina, Higher School of Economics National Research University, Saint Petersburg Russia, gromovanat@list.ru, ORCID ID: https://orcid.org/0000-0003-0356-2159

\section{Introduction}

Arkady and Boris Strugatskys are acclaimed as landmark figures in Russian twentieth century literature, with their main contribution being to the science fiction genre, which they imbued with philosophical and religious meanings (Tam- 
maro 1; Miloslavskaâ 2008: 3). Spatial images, as is often the case with science fiction literature, play a significant role in their prose, participating in the binary opposition of the known and the unknown. Main personages frequently have to travel to new places with different missions, which constitutes the majority of the Strugatskys' plots (Èverstov 307).

The present paper analyses Monday starts on Saturday (Ponedel'nik nachinayetsya $v$ subbotu, 1964), defined by Eugene Kozlowski as 'soft science fiction' (Kozlowski 14), from the perspective of spatial organization and spatial images creation. The question of the spatial organization of the tale, though raised in research literature, has not been profoundly studied yet (Vasilaš, Vološinova 229). This tale combines the properties of fantasy and science fiction, making use of both genres potential to create a new narrative form with its own spatial qualities. The action of the tale takes place in a parallel reality called 'mago-space' by the narrator. It exists on par with the ordinary world, as it happens in fantasy prose. Like fantasy, the story features a range of well-known mythological creatures and objects, but contrary to this genre, constant allusions are made to works of world literature, turning Monday starts on Saturday into a postmodernist text (Miloslavskaâ 2014: 171). Thus, the space of the tale is characterized by ambiguous properties of the space that may resemble the real world or be explicitly fictionalized: the protagonist, initially belonging to the real world, ends up in the magical world inhabited with creatures originating in world culture - literature and folklore, but also by scientists, administrators, journalists and militia. The text also includes some elements of science fiction by absolutising this magical world, as the heroes lose all the connection with reality and stay within the limits of their magical institution. In addition, science fiction is incorporated by addressing the advances of science and technology, although based on magical foundations. Finally, travelling to the imaginary future as presented in science fiction allows the authors to dwell on the genre poetics.

The category of space plays a crucial role in the tale, which is reflected in the earlier version of the title: The Seventh Heaven (Sed'moye nebo), Land of Magicians (Strana magov), Republic of Magicians (Respublika magov) (Strugackij, Strugackij 338); within the 'mago-space' of the text various sub-spaces that receive pseudo-scientific names can be identified (M-field, hyperfield, etc.). The events are determined by the chosen space type and cannot happen anywhere else, despite their stressed fictionality.

The analysis is conducted within the framework of the semiotic approach to the spatial organization of a literary text, as this seems to be an approach best compatible with the Strugatskys' prose. Many images of the tale are references to cultural traditions rather than attempts to create a visually represented space per se. We analyze the three parts of the tale in their succession and pinpoint the 
dominant principles in their organization, identifying their origins. Next, we establish a number of elements that unify the three parts, and finally we dwell on what message could be conveyed by the chosen patterns. We argue that the first part of the tale presents space as it is done in Russian fairy tales and in classical literature. In the second part, the narrative moves on to the mythological way of organizing space. In the final part, space gradually loses its tangible features and becomes the space of intellectual quest - scientific and philosophical. The connection between the parts is maintained, among other means, by spatial images. However, the paratextual elements (epigraphs, postscript and commentary) reveal the artificial nature of any spatial model.

\section{Part 1: "It was more like Alice in Wonderland"}

The first part of the tale, Commotion over the divan (Suyeta vokrug divana), is built around a tangible object that transforms the real space into a magical one. This object is a divan (a sofa), and different personages want it for their possession. For the narrator and the protagonist, Alexander Privalov, spending a night on this divan becomes an initial stage in his travel to a new life in the imaginary northern town Solovets (a reference to the notorious Solovki archipelago). A possible meaning of the image is commented on by Kozlowski: "The etymology of the word 'divan' is from the Persian where it means a 'collection of poems'. Thus the word 'divan' also suggests poetry, fiction, imagination, and their powers to transform reality" (Kozlowski 100).

The real location of Privalov's journey, although bearing easily recognizable features of the Soviet "byt", are tinted with the legacy of Russian and world culture. The bond with Russian culture is established through the concept of the province, which arouses reminiscences to a certain national literature tradition from Nikolay Gogol to Ilya Ilf and Evgeny Petrov, and is stressed by explicit citations. On the other hand, the distance from the urban centres leashes the folk potential of the province image, which becomes a treasury of old traditions and to some extent resists modernisation.

The protagonist's travel to meet his friends (who never appear in the story) for a reason which is never explained, is interrupted by a sudden encounter. The car that the narrator drives is a substitute of a horse or a wolf, and, as often happens with vehicles in fairy tales, is not his own. Just like a fairy tale hero, Privalov does something good for two complete strangers: picks them up when they hitchhike near a forest, and in return they arrange his lodgings for the night, showing him the way to a magical kingdom, and ultimately his career at the National Institute for the Technology of Witcheraft and Thaumaturgy. 
The lodgings take place at a museum, which is at the same time a house of Baba Yaga: the house presumably has chicken legs, and the hostess, Naina Kievna Gorynych, bears a striking resemblance to the old witch of Russian folklore. This place therefore combines the features of folklore (talking animals, a mermaid, a dragon) and technical progress: a telephone - "a very modern piece of equipment in white plastic" (Strugatsky, Strugatsky 24), a trade union meeting of witches, etc.

Interestingly, the narrator seems quite oblivious to the fairy tales traditions. Instead, he chooses a western way of construing the reality. Thus, the story is enriched with written culture images due to allusions derived from world literature, starting with Alexander Pushkin up to Charles Dickens (Gromova). The allusions are interpreted by the narrator in a certain way that transforms the space into a new one. The connection with literature dictates the choice of epigraphs that make a link to the gothic discourse, in which a hero occasionally has to stay overnight at a scary place. It also reflects the narrator's wish to explore reality from a scientific perspective. Also, the space is stretched through tangible objects. For example, a table cloth on the dining table encompasses the vast spaces of the world literature: the hungry hero remembers different episodes where literary personages had meals. The book that Privalov constantly resumes reading is a different narrative each time (Alexey Tolstoy's novel, a law book, a book on syntax, a collection and study of literature written by people with mental disorders). Thus, the Strugatskys exploit the generic potential of objects that in fantasy often serve the model of the world (Nesterova 58).

Reality, thus, is constructed with the help of cultural texts, which Irina Vaganova defines as 'mental sublocations' (Vaganova) and Kozlowski refers to as 'discourses' (Kozlowski 10). The space in which a personage functions is determined by the tradition behind the personage. In the following parts the same principles of spatial organization are used, but the sources are different.

\section{Part 2: "The year's on the turn, Saturn's in the constellation of Libra"}

Unlike the first part, the second one, Vanity of Vanities (Suyeta Suyet), is almost exclusively located in the institute. It becomes clear why the Strugatskys spoke of the tale as "a story of fantastic scientists" (Strugatsky, Strugatsky 419). The unity of space and time is provided by the situation: the narrator is appointed to stand a night watch of the building on the New Year's Eve. The first chapter of the part introduces the gallery of the main characters, followed by a long description of the building itself. 
The name of the institute is a reference to the utopia genre, as it is a place that does not exist (The Russian abbreviation sounds like 'nothing'), on the one hand, and depicts a kind of ideal, on the other (Tatarchenko, Peters 246). The book paradoxically combines the elements of satire and utopia. Targeting real high schools, with their deficiencies and flaws, NITTWIT is still a place where the narrator and most other personages feel happy. What is more, it is a place where happiness is constantly being searched for (in the Department of Linear Happiness) and studied (thus, Magnus Redkin collects varied definitions of happiness).

The setting of the second part is situationally and culturally dictated. The action takes place on New Year Eve, the ritual moment of the temporal shift when creatures from the alien world may enter our world through a crevice between the years (it explains why Vybegallo's notorious experiment occurs on the night). Secondly, Privalov's night watch allows the authors to naturally incorporate the NITWITT organization description, and the part turns into a demonstration of the Institute's structure, which reminds of a mythological space model.

The space in the second part, contrary to the first, follows a distinct mythological model, both in terms of its organization and the personages functioning in it. While in the former cultural artifacts are presented as museum exhibits, in the latter they come alive and start functioning and interacting, or rather colliding. Whereas the space of this part seems to become narrower in comparison with the previous one, its context is broadened significantly. During the first encounter with the magical world, Privalov operated mainly with notions from Russian fairy tales and the western literature, but this time the scope includes numerous references to the world's history and culture - Scandinavian, Greek and Roman myths, Arabian fairy tales, Russian folklore, events and real people from both medieval and modern history. The personages embody myths and archetypes at the same time as bearing psychological and social characteristics of the modern world (Tolokonnikova 31). For example, Fyodor Kivrin, who has lived in several epochs, in contemporaneity presents a figure of an outcast academic. Thus, the Strugatskys, apart from creating a vivid personage, demonstrate the archetypal meaning of the social realia.

In stark contrast to the completely 'horizontal' first part, the second part is arranged vertically, as the institute is organized as a system of levels, starting with the basement inhabited by monsters that correspond to creatures from chthonic myths. Each storey is occupied by a certain department and presents a particular level of the world structure organised in compliance with a different set of laws. Each one is a complete system independent from the others: Merlin coexists with augurs, a vampire guards the Hecatoncheires. They present different values for the narrator, but none of the departments can be abolished, even though they may become old-fashioned, pointless or even harmful. It can be explained not only by 
the Strugatskys' satirical outlook on the contemporary higher school, but also by the fact that the departments are projections of human sets of values of different epochs and cannot be revoked.

The role of the world tree in this vertical structure is fulfilled by "the formal staircase, which I could only ever remember being used on one occasion" (Strugatsky, Strugatsky 94). Other characters do not use it, being able to fly or transgress. A staircase features in many mythologies and organizes the world hierarchically (Toporov 587). The image of the staircase highlights the mythological nature of the spatial model and the narrator's role of a guide and novice who again solves another riddle.

Horizontally the space is infinite and at the same time secluded: "to the right and left of the entrance hall the institute extended for at least a kilometre, and yet absolutely all of the windows looked out on to the same crooked street and the same «emporium»" (Strugatsky, Strugatsky 96). The narrator's night watch is therefore pointless and its only function is to show the reader the ranges of values stored in the institute. The part is not only a museum tour, though, but the realization of two major mythological plots connected with New Year or Christmas. On this night Professor Vybegallo completes his experiment creating the ideal man: "the model of Man entirely unsatisfied, the Model of Man gastrically unsatisfied, and the model of Man totally satisfied" (Strugatsky, Strugatsky 84). The three initial models of man reveal the cyclic nature of the experiment and also refer to the myth of a dying and resurrected god. However, this myth turns out to be distorted as the experiment fails because Vybegallo does not realize the true meaning of the myth. Instead of archetypical categories, he uses a vulgar materialistic idea of progress and rather than creating a new man hatches a 'titanic consumer'. The myth immediately turns into its opposite, the eschatological myth, as the cadaver threatens the whole world's structure: "He'll just grab all the material valuables he can lay his hands on, then he'll roll up space, wrap himself up as a pupa and halt time" (Strugatsky, Strugatsky 156).

Vybegallo's cadavers are opposed to the image of other employees of NITTWIT, who represent the Soviet dream type of 'new men' eager to sacrifice their selfish interests to the common good and scientific advance. The new man is actually a researcher, "the transitional stage between Neanderthal and Magician" (Strugatsky, Strugatsky 121). Svetlana Tolokonnikova sees in these scientists new cultural heroes, demiurges, who create a new world and protect it from chaos. In her view, the whole tale presents an ironic neomythological narrative that is based on the industrial novel (Tolokonnikova 27). This idea of the spiritual development of man is continued in the third part. 


\section{Part 3: "I felt as if I was reading the final pages of a gripping detective novel"}

In the third part, All kinds of commotion (Vsyacheskaya sueta), space is less homogenous than in the first two parts as it is represented in blocks. The institute itself, presumably familiar to the reader, is less thoroughly described. What is more, the events of one chapter are located in the virtual space of Privalov's journey to the described future. Further action takes place in the locus of an office where the physical characteristics of space lose their relevance, while the understanding of space reaches a new level - scientific and philosophical.

The beginning of the part includes the episode with a time machine that depicts Privalov's journey to the described future. The latter is contrasted by the narrator to the real space: after his returning from it, "everything seemed so material, so solid and substantial" (Strugatsky, Strugatsky 177). The Strugatskys satirize modern science fiction prose because it is discrete, devoid of material features and full of clichés. The passage is a critique of science fiction as compared to more ancient genres and traditions. The fictional characters that Privalov encounters prefer speech to actions and feelings, miss some physical detail due to the negligence of their authors and leave the impression of something transparent and unreal: "I was surrounded by a spectral world" (Strugatsky, Strugatsky 166). Here the Strugatskys parodise, according to their own confession, not the masters of science fiction that they admired, but imitators (Strugackij, Strugackij 448), and themselves (Suvin 159).

Another big episode shows a seemingly unimportant act of designing a newspaper "For Progressive Magic", which in fact bears meaningful connotations and becomes a metaphoric expression of the same idea. The institute's employees are endeavouring to physically arrange the information on a large sheet of paper just as the authors are organizing the space of the institute, with overlaps and gaps to be filled: "I have already tried laying out the texts this way and that way, but there is always some empty space left" (Strugatsky, Strugatsky 184). The same is true for writing poems, as Privalov and Stella are aspiring to fictionalize the real events (hooliganism of Ghoul (Viy) and Khoma Brut) into a meaningful system.

The final part becomes a clue to the whole book. The space of narration turns into a space of personages' thoughts and their intellectual quest, which may occur anywhere. As Privalov and his colleagues make several attempts to solve the mystery of the dying and resurrected parrot, and afterwards, the secret of the director Janus Nevstruev (who is "one person in two"), they move from one office to another without any change to the plot. In other words, they hardly notice the space around them. However, it is through space that they ultimately solve the mystery 
and understand that Janus and his parrot live backwards in time: "I could feel it was awfully important, that Petri dish... The unity of place!..." (Strugatsky, Strugatsky 215), but it is rather the idea of space than a particular location.

Despite the previous criticism of science fiction narrative, the space of the whole part eventually starts sharing the features of the fictional space: it lacks detail or a sensuous perspective, while in the first two parts the authors never overlooked this aspect. That is how the whole part becomes the realization of Roman's idea about travelling to the described present, the fictional character of which is underlined by the postscript and commentary. Thus, the Strugatskys create a metatext, writing a fairy tale about a fairy tale (Miloslavskaâ 2014: 174), or, rather, a myth about a myth.

No matter how abstract the space at the end of the novel may be, it is also loaded with mythical connotations. The literal realization of the two-faced Janus myth turns into a tangible form of Albert Einstein's idea. The idea of progress has a counterproductive meaning: moving on as a researcher, Janus reaches the point at which he cannot go forward and turns back, to regress. His destiny follows that of Sabaoth Baalovich Odin, who "could do anything at all. And yet he was unable to do anything at all" (Strugatsky, Strugatsky 181). This recurring theme seems to imply the endless character of the narrative itself.

\section{Unifying elements: "A material body in an ideal world, an ideal body in the real world"}

As we have seen, Monday starts on Saturday demonstrates a complex of various space models. The whole narrative of the tale may be represented through Yury Lotman's idea of semiosphere that includes several sign systems, partly overlapping, but very different (Lotman 252-253). Looking at these numerous models, it is clear that there must be a mechanism to unite this composite structure. It is done, among other techniques, through the organization of space: each object or locus can be connected with a certain literary or cultural tradition. Another technique can be called space concentration. When analyzing the plot structure of the tale, one can notice that the plot tends to focus around a particular point. The choice of such points is systemic and forms two parallel structures. Whereas the first and the third parts have one focal point, the central part has two.

The first part of the book, The Commotion over the divan, as it is clear from the title, revolves around the image of the divan. This piece of furniture causes conflicts between several NITWITT employees, who may see it as either an object or an instrument of research, or as a precious exhibit that requires protection. The main character chances to spend a night on this divan and is not only transported 
to a magical reality, but is involved in this conflict. Solving the mystery of the divan leads Privalov to discovering NITWITT itself and understanding the behaviour of other personages.

This structure is mirrored in the third part of the tale, where the space is concentrated around a Petri dish. Solving the mystery of the parrot's 'resurrection' in its turn leads the characters towards the solution of the mystery of their director, who lives backwards in time. Remarkably, both the divan and the petri dish share some features: they are both described as something ordinary and absolutely non-magical: "What has it got to do with the divan? I've never heard any fairytales about divans. There was a flying carpet. There was a magic tablecloth [...]. But there wasn't any magic divan. People sat or lay on divans, a divan was a very solid object, very ordinary" (Strugatsky, Strugatsky 59).

The rest of the space in these two parts is organised in circles around the central objects: the divan is placed in the room, which is situated in the house surrounded by the yard, and further - by the town. The Petri dish is placed on the desk in the director's office, which is the centre of the institute environed by the same town. The further a locus is from the centre, the more profane it seems (Lotman 266), making the narrator ironic and satiric in his descriptions, whereas closer to the centre he becomes more earnest. This model of space refers to fantasy and ultimately the myth. In other words, the inner space forms a kind of magic circle where only special people can enter. Interestingly, Privalov, in the first part of the book, seems to intuitively feel this and starts guarding his room from intruders: "I blocked his way. I don't know why I did it" (Strugatsky, Strugatsky 49). In the second part, his role of a guardian is stressed, and in the third one, only the most devoted researchers form a team that brainstorms the riddle.

The second part of the book demonstrates the same model of a closed, sacred space and develops it in the image of the institute itself. Here Privalov's mission of guarding this space becomes obvious, as he is given the task to night watch the Institute on New Year's Eve: "Not a single living soul must get in, and none of the others must get out" (Strugatsky, Strugatsky 76). The first climax of the part reveals his failure to do it, as dozens of employees flood the building in order to resume their work. This scene is described as a catastrophe, but Privalov feels unable and unwilling to prevent it, as this movement towards the centre of the world is only natural: "I no longer felt the slightest desire to combat these infringements, since these people had fought their way here through a blizzard at midnight on New Year's Eve because they were more interested in finishing up some useful job or starting up a completely new one than in dissolving their wits in vodka $[\ldots]$ " (Strugatsky, Strugatsky 119-120).

Yet there is one more climax in this part, which demonstrates the opposite scene of the world drawn to its focal point not from outside, but from within. 
This catastrophe is connected with Vybegallo's experiment to create Man totally satisfied: "The ground shifted and began to tremble [...]. I saw the edge of the horizon creeping towards me horrifically" (Strugatsky, Strugatsky 152-153). This eschatological episode collides the ideal world of intellectual enthusiasts with the anti-world of material desires. Remarkably, prior to the experiment the characters argue over the possibility to conduct it within the Institute. It seems that by driving it outside Janus separates the two focal points and thus prevents the end of the world.

\section{Final remarks: "No sensible reader will ever believe it"}

It has been shown how the tale is organised spatially. The Strugatskys seem to create the space typical of certain discourses. However, a closer look at the qualities of space reveals its discrepancy from the original genres. For example, although the locations of the first part employ some properties of the fairy tale, their function is very different from that of the folktale. While in the latter magical objects serve to assist the hero in his transportations (Lihačev 338), in Monday starts on Saturday magical objects are a source of the protagonist's troubles and retard him on his way. The divan brings chaos to his life, due to the unchangeable five-kopeck piece he is detained by the militia, and the magical wand nearly injures him. In this way, the 'resistance of the space' (Lihačev 333) is heightened, in contrast to the fairy tale. On the other hand, the space includes many signs of the real world - the Strugatskys even drew a topographic map of Solovets.

In the second part the very act of writing down a myth contradicts its essence: a myth cannot be recorded. What is more, the Strugatskys tend to refer to myths not in their original version, but in their later interpretations. This reconstructive intertextuality (Gromova 181) questions the veracity of the narrative. For example, Merlin comes not from medieval legends, but from Mark Twain's novel - in actions, in appearance, and in the language. Also, while myth is fundamentally antihistorical, the second part endeavours to combine myth and history, placing mythical heroes in real surroundings.

The third part seems to demonstrate the concurrency of the scientific discourse with the presented reality of the intellectual quest: the narrator uses the language and structures the texts as it would be done in a popular scientific paper. However, this harmony turns out to be illusionary when the narrator adds a Postscript, in which he reproaches the authors with misusing terminology and distorting the real events. This shows that in fact the space was fictional, artificially created.

The Strugatskys do not hide the discrepancy between the seeming attributes of space and the authentic space, involving the reader in a literary game. In his 
research Kozlowski (Kozlowski 99) demonstrates that the same is true for the linguistic level of the text: the authors constantly put on some 'mask' only to publicly take it off later. First, they create an illusion of some space and then debunk it. Just like Privalov travels to the described future to reveal the flaws and clichés of literature, the Strugatskys in their book travel to the described present - the idea suggested by Roman Oira-Oira and admired by the narrator - and show how an illusion of reality is created in a literary text. This may explain why the Strugatskys' "magic is far stranger and more random" than in most fantasy stories (Roberts viii).

\section{Conclusion}

The analysis of the organization of the space of Monday starts on Saturday indicates that spatially the tale is built in a sophisticated manner. On the one hand, the three parts produce the impression of creating the space of a fairy tale, myth, and science each. They deploy objects and features typical of these three discourses in order to create the corresponding models. The first part deploys the potential of the Russian fairy tale, including its spatial organization: the events take place on the horizontal level, and the center and the periphery are clearly differentiated. The second part moves on to the hierarchical model of space typical of mythology and divides the space into "layers". The third part operates with less tangible space images; the actions are concentrated on the level of cognition and intellectual quest, the stimulus for the research being the question of the space-time correlation.

Nevertheless, the seemingly smooth shift from one system to another is complicated by the title, epigraphs, and the postscript. The presence of metatextual elements and the complex relations between the images of the authors and the narrator create the impression of the inaccuracy and discrepancy of the vantage points. This questions the authors' expertise and makes the reader look closer at the tale's construction. Playing with the narrative's veracity and the narrator's/ authors' authority achieves the effect that all three parts not only demonstrate a digression from the imitated space models, but intentionally draw the reader's attention to the authors' 'mistakes' and highlight the fictional nature of the tale. The mago-space of Monday starts on Saturday is actually the space of a literary work as it is, and the whole tale becomes a story of how a literary work is created. In essence, "travelling to the described present" advocated by Oira-Oira is realized by Privalov's-Strugatskys' writing down the tale. 


\section{Bibliography}

Èverstov, Maksim. "Motiv putešestviâ v antiutopičeskih romanah brat'ev A. i B. Strugackih". Filologiâ i obrazovanie: 80 let razvitiâ russkoj slovesnosti v respublike Saha (Âkutiâ). Âkutsk, Interaktiv-plûs, 2016, p. 305-307.

Gromova, Natal'â. "Zarubežnye literaturnye allûzii v povesti Strugackih Ponedel'nik načinaetsâ v subbotu". Russkij tekst, 6, 2001, p. 179-196.

Kozlowski, Eugene Zeb. Comic codes in the Strugatskys'tales "Monday begins on Saturday” and "Tale of the Troika". Moskva, Maal, 1994.

Lotman, Ûrij. Semiosfera. Sankt-Peterburg: Iskusstvo-SPB, 2010.

Miloslavskaâ, Viktoriâ. "Mifopoetika i intertekstual'nost' kak sposob rasšireniâ hudožestvennogo prostranstva skazki brat'ev Strugackih Ponedel'nik načinaetsâ v subbotu". Gumanitarnye i ûridičeskie issledovaniâ, 1, 2014, p. 171-174.

Miloslavskaâ, Viktoriâ. Tvorčestvo A. i B. Strugackih v kontekste èstetičeskih strategij postmodernizma. Avtoreferat dissertacii na soiskanie učenoj stepeni kandidata filologičeskih nauk. Stavropol', 2008.

Lihačev, Dmitrij. Poètika drevnerusskoj literatury. Moskva, Nauka, 1979.

Nesterova, Evdokiâ. "Veŝ': mesto v strukture mira proizvedeniâ (na materiale fèntezi)". Novyj filologičeskij vestnik, 2 (41), 2017, p. 51-62.

Roberts, Adam. "Introduction”. Arkady Strugatsky, Boris Strugatsky. Monday starts on Saturday. Transl. by Andrew Bromfield. London, Gateway, 2016, p. vii-xi.

Strugackij, Arkadij, Boris Strugackij. Polnoe sobranie sočinenij v 33 tomah. Sankt-Peterburg, Izdvo Sidorovič, 2018.

Strugatsky, Arkady, Boris Strugatsky. Monday starts on Saturday. Transl. by Andrew Bromfield. London, Gateway, 2016.

Suvin, Darko. Positions and presuppositions in Science Fiction. London, Palgrave, 1988.

Tammaro, Elizabeth. Communism's futures: Intelligentsia imaginations in the writings of the Strugatsky brothers. Orlando, Thesis, 2014.

Tatarchenko, Ksenia, Benjamin Peters. "Tomorrow begins yesterday: data imaginaries in Russian and Soviet science fiction". Russian Journal of Communication, 9 (3), 2017, p. 241-251.

Tolokonnikova, Svetlana. "Utopičeskij neomifologizm brat'ev A. i B. Strugackih v povesti Ponedel'nik načinaetsâ v subbotu”. Voprosy russkoj literatury, 3 (33), 2015, p. 26-33.

Toporov, Vladimir. "Lestnica". Mify narodov mira. Ėnciklopediâ. Moskva, Izdatel'stvo "Sovetskaâ ènciklopediâ", 2008, p. 587. Web. 20.11.2020. https://www.indostan.ru/biblioteka/ knigi/2730/3412_1_o.pdf.

Vaganova, Irina. Azykovaâ igra v mental'nyh prostranstvah proizvedenij hudožestvennoj fantastiki (na materiale tvorčestva A. i B. Strugackih). Avtoreferat dissertacii na soiskanie učenoj stepeni kandidata filologičeskih nauk. Ekaterinburg, 2009.

Vasilaš, Valeriâ, Tat'âna Vološinova. "Prostranstvennaâ organizaciâ fragmenta povesti Strugackih Ponedel'nik načinaetsâ v subbotu". Nedelâ nauki SPbPU. Sankt-Peterburg, SPbPU Petra Velikogo, 2020, p. 229-231. 